\title{
PARTISIPASI MASYARAKAT DALAM MENINGKATKAN KUALITAS PELAYANAN PERTANAHAN
}

\author{
COMMUNITY PARTICIPATION \\ IN IMPROVING LAND SERVICE QUALITY
}

\author{
Euis Salbiah ${ }^{1 *}$, Irma Purnamasari², Maria Fitriah ${ }^{3}$, Agustini ${ }^{4}$ \\ 1,2Program Studi Administrasi Publik, Fakultas Ilmu Sosial dan Ilmu Politik, Universitas \\ Djuanda, Jl. Tol Ciawi No. 1, Kotak Pos 35, Bogor 16720 \\ 3,4Program Studi Sains Komunikasi, Fakultas Ilmu Sosial dan Ilmu Politik, Universitas \\ Djuanda, Jl. Tol Ciawi No. 1, Kotak Pos 35, Bogor 16720 \\ *Korespondensi: Euis Salbiah. Email: euis.salbiah.adn@unida.ac.id
}

(Diterima: 09-10-2019; Ditelaah: 14-11-2019; Disetujui: 09-12-2019)

\begin{abstract}
This research aims to describe the community participation in improving the land service quality in Cianjur Regency. In accordance with the aim, this research is a descriptive research used as a method to find out a comprehensive and realistic description about the community participation in improving the land service quality in Cianjur Regency. Data of this research are collected by observation, interview, questionaire and documentation. In this research, the improvement of public service quality including the land service quality is needed to build the public trust on the public apparatuses as the provider of public services by developing the community participation as a tool to improve the public servive. The community participations consist of articulating complaint, aspiration, thought, interest and problem of public service. The other forms of community participation are to find out information or other access, initiative (voice) and appreciation (input) of the public, and mechanism for involving in decision making. The community participation can be effectively managed by providing the tools of participation, assigning the competent apparatuses, handling the complaints as a form of community participations, and following up the complaints.
\end{abstract}

Key words: Community Participation, Kabupaten Cianjur, Land Service Quality, Public Service.

\begin{abstract}
ABSTRAK
Penelitian ini bertujuan untuk menggambarkan partisipasi masyarakat dalam meningkatkan kualitas pelayanan pertanahan di Kabupaten Cianjur. Sejalan dengan tujuan tersebut, penelitian ini merupakan penelitian deskriptif yang digunakan sebagai metode untuk memperoleh deskripsi yang utuh dan realistis tentang partisipasi masyarakat dalam meningkatkan kualitas pelayanan pertanahan di Kabupaten Cianjur. Data penelitian dikumpulkan melalui observasi, wawancara, angket dan dokumentasi. Dalam penelitian ini, peningkatan kualitas pelayanan publik termasuk kualitas pelayanan pertanahan diperlukan untuk membangun kepercayaan masyarakat terhadap aparatur sebagai penyedia pelayanan publik dengan menjadikan partisipasi masyarakat sebagai sarana untuk melakukan perbaikan pelayanan publik. Partisipasi masyarakat dapat berupa penyampaian keluhan/pengaduan, aspirasi, pemikiran, kepentingan dan permasalahan dalam pelayanan publik. Bentuk lain partisipasi masyarakat dapat berupa menemukan informasi atau akses lainnya, inisiatif (voice/suara) dan apresiasi warga (masukan), serta mekanisme untuk terlibat dalam pengambilan keputusan. Partisipasi masyarakat dapat dikelola secara efektif dengan menyediakan sarana partisipasi, menugaskan pelaksana yang kompeten, menangani keluhan/pengaduan sebagai salah satu bentuk partisipasi masyarakat dan menindaklanjuti keluhan/pengaduan.
\end{abstract}

Kata kunci: Partisipasi Masyarakat, Kabupaten Cianjur, Kualitas Pelayanan Pertanahan, Pelayanan Publik.

Salbiah, Euis, Purnamasari, Irma, Fitriah, Maria \& Agustini. (2020). Partisipasi Masyarakat Dalam Meningkatkan Kualitas Pelayanan Pertanahan. Jurnal GOVERNANSI, 6(1): 36-42. 


\section{PENDAHULUAN}

Peranan masyarakat selaku pengguna/penerima pelayanan dalam rangka meningkatkan kualitas pelayanan publik memerlukan penyediaan pelayanan publik yang transparan, akuntabel, sesuai standar pelayanan berdasarkan persamaan perlakuan dan keterjangkauan masyarakat. Partisipasi masyarakat menurut Peraturan Pemerintah Republik Indonesia Nomor 45 Tahun 2017 tentang Partisipasi Masyarakat Dalam Penyelenggaraan Pemerintahan Daerah adalah peran serta masyarakat untuk menyalurkan aspirasi, pemikiran, dan kepentingannya dalam penyelenggaraan pemerintahan daerah. Salah satunya melalui Indeks Kepuasan Masyarakat (IKM), yang merupakan tolok ukur untuk menilai tingkat kualitas pelayanan. Data IKM dapat menjadi bahan penilaian terhadap unsur pelayanan yang masih perlu perbaikan dan menjadi pendorong setiap unit penyelenggara pelayanan untuk meningkatkan kualitas pelayanannya.

Dalam Peraturan Menteri Negara Pendayagunaan Aparatur Negara Nomor 13 Tahun 2009 tentang Pedoman Peningkatan Kualitas Pelayanan Publik Dengan Partisipasi Masyarakat dinyatakan bahwa Indeks Kepuasan Masyarakat (IKM) adalah data dan informasi tentang tingkat kepuasan masyarakat yang diperoleh dari hasil pengukuran secara kuantitatif dan kualitatif atas pendapat masyarakat dalam memperoleh pelayanan dari aparatur penyelenggara pelayanan publik dengan membandingkan antara harapan dan kebutuhannya. Survei IKM bertujuan untuk mengetahui tingkat kinerja unit pelayanan secara berkala sebagai bahan untuk menetapkan kebijakan dalam rangka peningkatan kualitas pelayanan publik selanjutnya. Partisipasi masyarakat juga dapat berupa keluhan/pengaduan masyarakat atas pelayanan yang diterimanya. Pengaduan ini memerlukan upaya tindak lanjut penyelenggara layanan untuk melakukan pengelolaan pengaduan dengan efektif dan efisien untuk meningkatkan kualitas pelayanan.
Pengelolaan pengaduan menurut Peraturan Menteri Pendayagunaan Aparatur Negara dan Reformasi Birokrasi Nomor 24 Tahun 2014 tentang Pedoman Penyelenggaraan Pengelolaan Pengaduan Pelayanan Publik Secara Nasional adalah kegiatan penanganan pengaduan sesuai dengan mekanisme dan tata cara pengelolaan pengaduan. Untuk menjamin peningkatan kualitas pelayanan publik yang terus menerus dan berkelanjutan diperlukan manajemen pengelolaan pengaduan. Posisi tawar masyarakat di mata pemerintah menjadi meningkat dengan adanya partisipasi masyarakat, sehingga masyarakat selalu dilibatkan dalam pembangunan, baik dalam pengambilan keputusan maupun dalam pelaksanaan pembangunan. Metode peningkatan kualitas pelayanan publik dengan partisipasi masyarakat menurut Peraturan Menteri Negara Pendayagunaan Aparatur Negara Nomor 13 Tahun 2009 tentang Pedoman Peningkatan Kualitas Pelayanan Publik Dengan Partisipasi Masyarakat ditunjukkan pada Gambar 1.

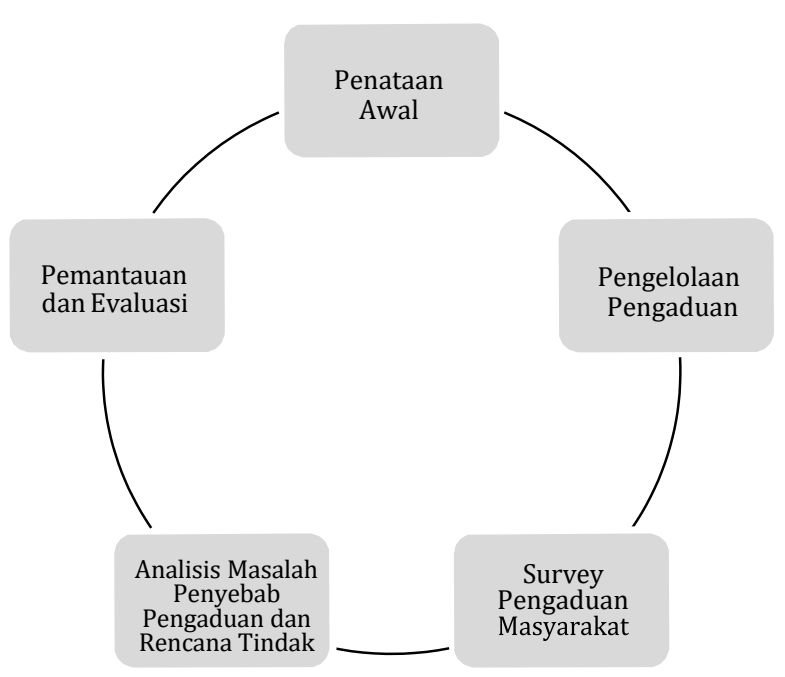

Gambar 1. Metode Peningkatan Kualitas Pelayanan Publik dengan Partisipasi Masyarakat

Gambar 1 menunjukkan keterkaitan sekuensial lima komponen utama yang ada di dalam metode peningkatan kualitas pelayanan publik dengan partisipasi masyarakat. Keberhasilan dan kualitas hasil pelaksanaan langkah sebelumnya akan 
menentukan keberhasilan dan kualitas hasil yang akan diperoleh pada pelaksanaan tahapan berikutnya. Berdasarkan latar belakang tersebut, penelitian ini bertujuan untuk menggambarkan partisipasi masyarakat dalam meningkatkan kualitas pelayanan pertanahan.

\section{MATERI DAN METODE}

\section{Konsep/Teori yang Relevan}

Partisipasi masyarakat, selain menjadi kata kunci dalam pembangunan, juga menjadi salah satu karakteristik dari penyelenggaraan pemerintahan yang baik (good governance).

Partisipasi (bahasa Inggeris: participation) secara etimologis berasal dari gabungan dua kata, yaitu pars (bahasa Latin) yang bahasa Inggerisnya part, artinya bagian atau peran, dan capere (bahasa Latin) yang berarti menangkap atau mengambil. Dengan demikian, partisipasi berarti mengambil bagian atau peran, sering dimaknai juga sebagai turut serta, mengikutsertakan, atau melibatkan diri (Seran, 2013: 431). Kamus Besar Bahasa Indonesia mengartikan partisipasi sebagai perihal turut berperan serta dalam suatu kegiatan, keikutsertaan, atau peran serta.

Masyarakat, yang berpartisipasi dalam pembangunan dan/atau penyelenggaraan pemerintahan, didefinisikan oleh Ralph Hinton sebagai setiap kelompok manusia yang telah hidup dan bekerja bersama cukup lama sehingga mereka dapat mengatur diri mereka dan menganggap diri mereka sebagai suatu kesatuan sosial dengan batas-batas yang dirumuskan dengan jelas (Fathurrahman, 2013).

Menurut Sumarto, partisipasi merupakan suatu proses yang memungkinkan adanya interaksi yang lebih baik antar stakeholders sehingga kesepakatan-kesepakatan dan tindakan yang bersifat inovatif lebih mungkin tercipta dalam proses deliberatif, dimana ruang untuk mendengarkan, belajar, refleksi dan memulai suatu aksi bersama terjadi (Fathurrahman, 2013). Dalam Undang-Undang Nomor 25 Tahun 2004 tentang Sistem Perencanaan Pembangunan Nasional, penjelasan Pasal 2 ayat (4) huruf d), partisipasi masyarakat didefinisikan sebagai keikutsertaan masyarakat untuk mengakomodasikan kepentingan mereka dalam proses penyusunan rencana pembangunan.

Cohen dan Uphoff menguraikan bentuk-bentuk partisipasi yang terbagi ke dalam empat bentuk, yaitu: (1) partisipasi dalam pembuatan keputusan (participation in decision making), (2) partisipasi dalam pelaksanaan (participation in implementation), (3) partisipasi dalam menerima manfaat (participation in benefits), dan (4) partisipasi dalam evaluasi (participation in evaluation) (Ndraha, 1990). Thubany menjelaskan empat aspek yang menjadi indikasi terbangunnya partisipasi, yakni: 1) informasi atau akses lainnya, 2) inisiatif (voice/suara) dan apresiasi warga (masukan), 3) mekanisme pengambilan keputusan, dan 4) kontrol/pengawasan (Fathurrahman, 2013).

Partisipasi memiliki peran penting, bagi masyarakat. Partisipasi merupakan media untuk menyuarakan preferensi dan mempengaruhi pembuatan keputusan. Marschall mengemukakan bahwa the purpose of citizen participation is as much to communicate preferences and influence policymaking as to assist in the implementation of the public good and to contribute to its preservation and continuation (Utomo, 2008).

Partisipasi masyarakat juga dapat dilihat dalam pelayanan publik yang diberikan/disediakan oleh pemerintah. Pelayanan publik adalah kegiatan atau rangkaian kegiatan dalam rangka pemenuhan kebutuhan pelayanan bagi setiap warga negara dan penduduk atas barang, jasa dan/atau pelayanan administratif yang disediakan oleh penyelenggara pelayanan publik (Pasal 1 angka 1 Undang-Undang Nomor 25 Tahun 2009 tentang Pelayanan Publik). 
Pelayanan publik dimaksud berbentuk: (1) pelayanan administratif/administrative services, (2) pelayanan kebutuhan dasar/basic need services, dan (3) pelayanan infrastruktural/infrastructural services (Budiarto, Krisna \& Seran, 2005). Pelayanan publik mencakup pelayanan barang publik dan jasa publik serta pelayanan administratif (Pasal 5 ayat 1 Undang-Undang Nomor 25 Tahun 2009 tentang Pelayanan Publik).

Pelayanan publik membutuhkan partisipasi masyarakat dalam rangka meningkatkan kualitas pelayanan publik. Dalam hal ini, partisipasi masyarakat berbentuk penyampaian keluhan/pengaduan, aspirasi, pemikiran, kepentingan dan permasalahan sebagai umpan balik dalam rangka perbaikan dan peningkatan kualitas pelayanan publik (Purwanto, 2005; Dwiyanto, 2005).

\section{Metode}

Penelitian ini dilakukan di Kabupaten Cianjur Jawa Barat. Metode penelitian yang digunakan adalah penelitian deskriptifkualitatif. Pemilihan pendekatan kualitatif dengan metode deskriptif didasarkan pada tujuan untuk memperoleh deskripsi yang utuh dan realistis tentang partisipasi masyarakat dalam meningkatkan kualitas pelayanan pertanahan. Adapun teknik analisis data yang digunakan dalam penelitian ini adalah data primer dan data sekunder dengan menguraikan, menafsirkan dan menggambarkan data yang terkumpul secara sistemik dan sistematik. Penyajian data tersebut menjadi lebih bermakna dan mudah dipahami digunakan interactive model analysis dari Milles dan Huberman (1992). Kegiatan analisis dalam model ini dibagi menjadi tiga tahap, yaitu reduksi data, penyajian data, dan penarikan kesimpulan.

\section{HASIL DAN PEMBAHASAN}

Kabupaten Cianjur merupakan salah satu kabupaten di Provinsi Jawa Barat yang terdiri atas 32 kecamatan, 342 desa dan 6 kelurahan, dengan jumlah penduduk mencapai 2.246.663 jiwa dan sebaran penduduk $585 \mathrm{jiwa} / \mathrm{km}^{2}$ di tahun 2017. Dari luas wilayah Kabupaten Cianjur 350.148 hektar, pemanfaatannya meliputi $83.034 \mathrm{Ha}$ $(23,71 \%)$ berupa hutan produktif dan konservasi, 58,101 Ha (16,59 \%) berupa tanah pertanian lahan basah, 97.227 Ha $(27,76 \%)$ berupa lahan pertanian kering dan tegalan, 57.735 Ha $(16,49 \%)$ berupa tanah perkebunan, $3.500 \mathrm{Ha}(0,10 \%)$ berupa tanah dan penggembalaan/ pekarangan, 1.239 Ha $(0,035 \%)$ berupa tambak/kolam, 25.261 Ha $(7,20 \%)$ berupa pemukiman/pekarangan, dan $22.483 \mathrm{Ha}$ (6.42 \%) berupa penggunaan lain-lain (Wikipedia).

\section{Bentuk Partisipasi Masyarakat Pengguna Pelayanan Pertanahan}

Bentuk partisipasi masyarakat berupa keluhan/pengaduan disampaikan kepada Kantor Pertanahan Kabupaten Cianjur sebagai wujud ketidakpuasan dalam pelayanan pertanahan. Rata-rata jumlah permohonan layanan pertanahan sebanyak $1.800-2.000$ pelayanan pertanahan setiap bulan. Dari jumlah tersebut, masih terdapat keluhan/pengaduan masyarakat akan pelayanan pertanahan di Kantor Pertanahan Kabupaten Cianjur. Dari total pengaduan masyarakat pengguna jasa layanan pertanahan, secara umumnya pengaduan tersebut berkaitan dengan pengaduan SOP melebihi waktu yang telah ditetapkan untuk jenis layanan pendaftaran sertifikat pertama kali, baik tanah adat maupun tanah negara. Di samping itu terdapat pengaduan terjadinya kesalahan produk sertifikat, kesalahan identitas atau salah ketik nama. Untuk kasus seperti ini, langsung ditindaklanjuti dan digantikan sertifikatnya. Sejalan dengan apa yang dikemukakan oleh Thubany terkait empat aspek yang menjadi indikasi terbangunnya partisipasi, yakni: 1) informasi atau akses lainnya, 2) inisiatif (voice) suara) dan apresiasi warga (masukan), 3) 
mekanisme pengambilan keputusan, dan 4) kontrol/pengawasan.

\section{Informasi atau Akses Lainnya}

Keberadaan informasi yang berasal dari Kantor Pertanahan Kabupaten Cianjur merupakan salah satu penyebab munculnya partisipasi, yaitu informasi yang berkaitan dengan penyelesaian sertifikat dari bagian informasi. Aduan bermula dari pemohon yang mengambil produk di loket pengambilan produk namun belum selesai pada waktu yang telah ditetapkan (4 bulan). Dari loket pengambilan produk tersebut, pemohon diarahkan ke bagian informasi untuk diberikan penjelasan mengenai produk yang belum selesai. Kemudian dilakukan pencatatan pengaduan dengan mengisi form daftar aduan. Pengaduan tersebut dicatat dalam buku monitoring daftar aduan dengan format kolom sebagai berikut: nomor, tanggal dokumen, jenis aduan, nomor berkas, tindak lanjut (terbagi dalam tindak lanjut sebelumnya dan tindak lanjut bulan ini), dan kolom keterangan. Berdasarkan keterangan petugas kantor pertanahan, SOP melebihi waktu yang telah ditetapkan disebabkan banyak hal, di antaranya pada saat pengukuran pihak-pihak yang berkepentingan tidak ada di tempat; faktor cuaca (kendala di alam) juga mempengaruhi waktu penyelesaian pengukuran sehingga SOP melebihi batas waktu. Informasi waktu penyelesaian sertifikat yang telah ditetapkan ternyata tidak sesuai dengan kenyataan.

\section{Inisiatif (Voice/Suara) dan Apresiasi Warga (Masukan)}

Bentuk ketidakpuasan masyarakat pengguna pelayanan biasanya disampaikan dalam bentuk keluhan/pengaduan, dengan harapan penyelenggara layanan dapat menindaklanjuti keluhan/pengaduan dengan wujud nyata pelaksanaan perbaikan secara terus-menerus. Saluran/sarana pengelolaan pengaduan yang tersedia di Kantor Pertanahan Kabupaten Cianjur adalah: (1)
Tempat/ruang informasi dan layanan pengaduan; (2) SMS ke 2409; (3) Pengaduan yang disampaikan melalui email Kantor Pertanahan Kabupaten Cianjur; (4) Formulir pengaduan dan alat tulis untuk pengaduan secara langsung kepada penyelenggara (lisan) melalui tempat/ruang informasi dan layanan pengaduan. Penerimaan pengaduan meliputi: (a) Pengaduan secara langsung kepada penyelenggara, yaitu pengaduan yang disampaikan secara lisan ke kantor pertanahan melalui loket informasi dan pengaduan dengan mengisi formulir pengaduan; (b) Pengaduan secara tidak langsung kepada penyelenggara, yaitu melalui kotak pengaduan, surat, teknologi informasi, seperti telepon, faksimili, website, surat elektronik/e-mail, layanan pesan singkat (SMS ke nomor 2409), dan jejaring sosial. Berdasarkan hasil wawancara dengan pengguna pelayanan pertanahan, mereka lebih mudah menyampaikan pengaduan secara langsung, sehingga bisa langsung diketahui status penyelesaian pengaduannya. Umumnya, pengaduan SOP melebihi waktu yang telah ditentukan untuk sertifikat pertama kali baik tanah adat ataupun tanah negara.

\section{Mekanisme Pengambilan Keputusan}

Momentum-momentum tertentu bisa menjadi pendorong bagi warga masyarakat untuk mengadukan keluhan (Utomo, 2008). Di Kantor Pertanahan Kabupaten Cianjur, pengarsipan pengaduan belum dilakukan dengan efektif dan efisien. Dokumen dan pelaporan pengaduan belum disimpan dengan menggunakan fasilitas digital namun tercatat dalam buku secara manual, sehingga terkendala dalam penemuan kembali apabila diperlukan. Pengarsipan belum dilakukan dalam bentuk data elektronik (soft copy). Semestinya pengelola pengaduan mempublikasikan jumlah dan status penyelesaian pengaduan kepada masyarakat pengguna layanan.

Penyelesaian pengaduan pelayanan publik seperti pelayanan pertanahan menempuh mekanisme sebagai berikut: 
1) Penyelenggara yang berwenang bertanggung jawab atas penyelesaian pengaduan.

2) Penyelesaian atau solusi yang diambil harus memenuhi kriteria spesifik, terukur, dapat dicapai, dan realistis.

3) Solusi dapat berupa penyelesaian pengaduan dan/atau rencana perbaikan pelayanan.

4) Solusi tersebut menjadi bagian perbaikan kinerja pelayanan penyelenggara.

5) Pengelola pengaduan wajib merahasiakan informasi yang bersifat pribadi, dan menurut derajatnya merupakan rahasia negara/jabatan sesuai dengan perundang-undangan.

6) Pengelola pengaduan wajib memberikan akses kepada masyarakat untuk melihat status penyelesaian pengaduannya.

7) Penyampaian penyelesaian pengaduan kepada pengadu paling lama 60 hari kalender sejak penyelesaian pengaduan.

Pengarsipan pengaduan dilakukan melalui setidaknya tiga cara berikut:

1) Dokumen dan pelaporan pengaduan disimpan dengan aman dan diupayakan menggunakan fasilitas digital, sehingga memudahkan penemuan kembali apabila diperlukan.

2) Pengarsipan dilakukan dalam bentuk data elektronik (soft copy). Apabila terdapat data hard copy wajib diubah menjadi data soft copy dan disimpan dalam database.

3) Pengelola pengaduan wajib mempublikasikan jumlah, dan status penyelesaian pengaduan kepada masyarakat.

\section{KESIMPULAN}

Partisipasi masyarakat dalam pelayanan publik seperti pelayanan pertanahan dapat berupa penyampaian keluhan/pengaduan, aspirasi, pemikiran, kepentingan dan permasalahan dalam pelayanan publik. Bentuk lain partisipasi masyarakat dapat berupa menemukan informasi atau akses lainnya, inisiatif (voice/suara) dan apre- siasi warga (masukan), serta mekanisme untuk terlibat dalam pengambilan keputusan. Partisipasi masyarakat tersebut dapat dikelola secara efektif dengan menyediakan sarana partisipasi, menugaskan pelaksana yang kompeten, menangani keluhan/pengaduan sebagai salah satu bentuk partisipasi masyarakat, dan menindaklanjuti keluhan/ pengaduan.

\section{DAFTAR PUSTAKA}

\section{Buku}

Budiarto, Diani; Krisna, Eri \& Seran, G. Goris. (2005). Perspektif Pemerintahan Daerah: Otonomi, Birokrasi, dan Pelayanan Publik. Bogor: FISIP Universitas Djuanda.

Dwiyanto, Agus. (2005). "Survai Warga Pengguna Pelayanan". Dalam: Mewujudkan Good Governance Melalui Pelayanan Publik (editor: Agus Dwiyanto). Yogyakarta: Gadjah Mada University Press.

Milles, M. B. \& Hubberman, A. M. (1992). Analisis Data Kualitatif. Terjemahan oleh Tjetjep Rohidi \& Mulyarto. Jakarta: UI Percetakan.

Ndraha, Taliziduhu. 1990. Pembangunan Masyarakat. Jakarta: PT Rineka Cipta.

Purwanto, Erwan Agus. (2005). "Pelayanan Publik Partisipatif". Dalam: Mewujudkan Good Governance Melalui Pelayanan Publik (editor: Agus Dwiyanto). Yogyakarta: Gadjah Mada University Press.

Seran, Gotfridus Goris. (2013). Kamus Pemilu Populer, Kosa Kata Umum, Pengalaman Indonesia dan Negara Lain. Edisi Pertama. Yogyakarta: Graha Ilmu.

\section{Jurnal}

Fathurrahman, Fadil. (2013). "Partisipasi Masyarakat Dalam Musyawarah Perencanaan Pembangunan Di Kelurahan Kotabaru Tengah", Jurnal Ilmu Politik dan Pemerintahan Lokal, 2(2). 
Salbiah, Euis; Purnamasari, Irma; Fitriah, Maria \& Agustini. (2019). "Improvement of Land Service Quality in Public Sector", International Journal of Sciences: Basic and Applied Research (IJSBAR), 43(2): 33-42.

Utomo, Sad Dian. (2008). Bisnis \& Birokrasi, Jurnal Ilmu Administrasi dan Organisasi, 15(3): 161-167.

\section{Peraturan Perundang-undangan}

Peraturan Menteri Negara Pendayagunaan Aparatur Negara Nomor 13 Tahun 2009 tentang Pedoman Peningkatan Kualitas Pelayanan Publik Dengan Partisipasi Masyarakat.

Peraturan Menteri Pendayagunaan Aparatur Negara dan Reformasi Birokrasi Nomor 24 Tahun 2014 tentang Pedoman Penyelenggaraan Pengelolaan Pengaduan Pelayanan Publik Secara Nasional.

Peraturan Pemerintah Republik Indonesia Nomor 45 Tahun 2017 tentang Partisipasi Masyarakat Dalam Penyelenggaraan Pemerintahan Daerah (Lembaran Negara Republik Indonesia Tahun 2017 Nomor 225).

Undang-Undang Nomor 25 Tahun 2004 tentang Sistem Perencanaan Pembangunan Nasional (Lembaran Negara Republik Indonesia Tahun 2009 Nomor 104).

Undang-Undang Nomor 25 Tahun 2009 tentang Pelayanan Publik (Lembaran Negara Republik Indonesia Tahun 2009 Nomor 112, Tambahan Lembaran Negara Republik Indonesia Nomor 5038).

\section{Laman}

Kamus Besar Bahasa Indonesia yang diakses pada tanggal 8 Desember 2019 pukul 16.34 Wib.

Wikipedia yang diakses pada tanggal 8 Desember 2019 pukul 17.00 Wib.

\section{UCAPAN TERIMA KASIH}

Terlaksananya penelitian ini tentunya mendapatkan kontribusi dari sejumlah pihak. Untuk itu, peneliti selayaknya menyampaikan terima kasih kepada: (a) Direktorat Riset dan Pengabdian Masyarakat, Direktorat Jenderal Penguatan Riset dan Pengembangan, Kementerian Riset, Teknologi dan Pendidikan Tinggi Republik Indonesia, yang telah membiayai penelitian ini, (b) Direktorat Riset dan Pengabdian Masyarakat Universitas Djuanda Bogor, dan (c) Fakultas Ilmu Sosial dan Ilmu Politik Universitas Djuanda Bogor, yang telah memfasilitasi penelitian ini. 